\title{
FEMALE POLITICAL REPRESENTATION IN EAC STATES
}

\author{
JUDIT BACI \\ UNIVERSITY OF PÉCS
}

\begin{abstract}
Almost all East African Community (EAC) member states have more than 30 percent female MPs in their national parliaments: Rwanda (61.3\%), Tanzania (37.2\%), Burundi (36.4\%), Uganda (34.3\%), Kenya (21.8\%), and South Sudan (28.5\%). What could be the reason for the fact that all EAC countries, except Kenya, are above the so-called 'critical mass' in the field of female political representation? In the last decades, both conflict and political transition have emerged in EAC countries. During the post-conflict period, gender norms and values (with a focus on gender quota regulations) have been implemented into national policies. The newly established liberal constitutions and gender policy creation have affected the status of East African women positively, although there is a big difference between the states concerning the effectiveness of gender policy-making. My paper (with the help of my field trips in Arusha and Kigali in 2015 and 2016) intends to contribute to a better understanding of EAC countries in transition, with an emphasis on the changing role of women in society, particularly in the important fields of gender politics and political representation.
\end{abstract}

The female political representation of each country can only be understood and interpreted in its own context, especially in the case of Rwanda. It is very difficult to draw conclusions or find general principles that apply to all Sub-Saharan States. I still think that it is necessary to take a look at and elaborate on the female political representation in EAC member states, focusing on Uganda. The reason is that the $\mathrm{EAC}$ as a regional organization treats the five member states as a union, and it has a sophisticated gender strategy applied in Rwanda, Uganda, Burundi, Tanzania, Kenya, and South Sudan.

The EAC is a regional cooperation between Rwanda, Burundi, Tanzania, Uganda, and Kenya (by this time South Sudan was not a member state). The EAC also defines reaching gender equality at all levels as one of its major priorities. The $4^{\text {th }}$ EAC Gender and Community Development Strategic Plan contains the strategies and policies that are to be used in the period between 2012 and 2016 (East African Community, 2011). To increase the number of female MPs in the member states' national parliaments is also defined as one of the key principles or aims. 
The figure below shows the ratio of female politicians in the national parliaments of EAC member states. Rwanda is not only the number one among EAC states, but also the world record holder with 61.3 percent of women MPs in its national parliament (IPU, 2018). Tanzania follows Rwanda with 37.2\%, then comes Burundi (36.45\%), Uganda (34.3\%), South Sudan (28.5\%), and Kenya (21.08\%) (IPU, 2018). According to the Inter-Parliamentary Union's statistics, the ratio of female MPs in EAC member states is above (except Kenya) the so-called critical mass. (See the figure below).

In the next paragraph, I will give a short introduction to the quota policies of Tanzania, Burundi, Kenya, and South Sudan. The case of Rwanda and Uganda will be analyzed in more depth later.

\section{Tanzania}

According to the regulation of the constitution, since 2005, "women members must not make up less than $30 \%$ in the National Assembly. The special seats for women are distributed among the political parties in proportion to the number of seats awarded to them in parliament." (Constitution, Articles 66 (1b) and 78 (1)). As we can see from the wording of the constitution, Tanzania has a reserved seat quota type. The latest elections were in 2015. Currently, female MPs hold 145 seats among the total 390 mandates (IPU, 2018).

\section{Burundi}

As the constitution points out: "For every three candidates who appear consecutively on a list, only two can be of the same ethnic group and at least one out of every four candidates must be a woman" (Article 168 of the 2005 Constitution). "The National

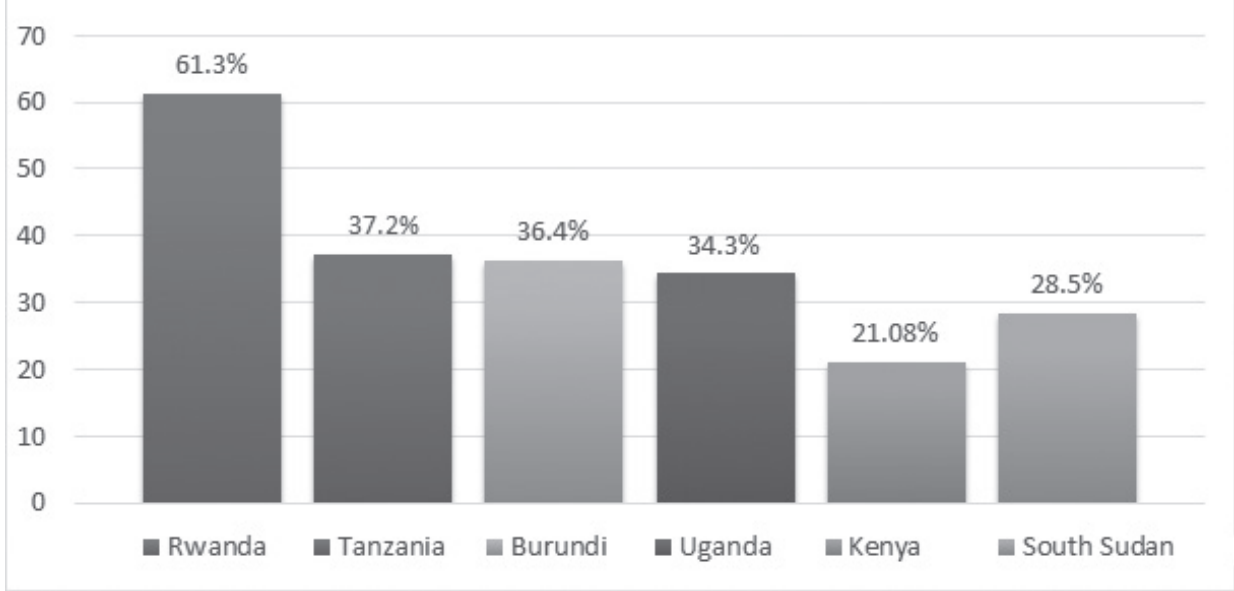

Female Political Representation in the EAC States in 2018.

Self-Generated Figure Based on IPU Data

(Inter-Parliamentary Union World Classification, 2018) 
Assembly is composed of $60 \%$ Hutu and $40 \%$ Tutsi, including at least 30\% women, as well as three deputies from the Twa ethnicity" (Article 164 (1) of the 2005 Constitution). Burundi, too, has a reserved seat quota type. The latest elections were held in June 2015. Right now there are 44 female MPs among the 121 representatives (IPU, 2018).

\section{Kenya}

Article 81 (b) of the Constitution of Kenya stipulates that the electoral system shall comply with the principle that "not more than two-thirds of the members of elective public bodies shall be of the same gender". The Constitution also reserves 47 seats in the National Assembly for women deputies elected from 47 counties. The latest elections were organized in June 2017. Nowadays 76 seats out of 349 belong to female MPs. The Commonwealth Report criticizes Kenya's progress concerning female political representation. As the report points out, the "actualization of the two-thirds rule in elective bodies is still a challenge and the political landscape continues to be dominated by the men due to their big numbers in the parties." (The Commonwealth, 2016: 10)

\section{South Sudan}

South Sudan is the newest member of the EAC. The country joined the organization in 2016. As the Constitution of South Sudan states, 'All levels of government shall: promote women's participation in public life and their representation in the legislative and executive organs by at least twenty-five percent as an affirmative action to redress imbalances created by history, customs, and traditions' (The Constitution of South Sudan, 2011, Article 16 (4a)). '(...) twenty-five percent representing women members shall be elected on the basis of proportional representation at the national level from closed party lists and fifteen percent shall be elected through proportional representation at the national level from closed party lists' (Article 60 (2); National Elections Act of South Sudan, 2012). The latest elections were held in August 2016. There are 383 seats in the national parliament and 109 seats are currently occupied by women.

In the following section, the female political representation of Uganda and Rwanda will be analyzed. The comparison drawn between the female political representation of Rwanda and Uganda has already appeared in the works of Longman (2006: 139-140), Powley (2005: 159), and Burnet (2008: 367).

\section{Uganda}

According to the $1^{\text {st }}$ clause of paragraph 78 of the Constitution of Uganda (1995), the 427 members of the parliament are elected as follows:

- 290 people: representatives elected directly by the majority in the constituencies

- 112 people: district female representatives

- 10 people: representatives of the Defense Forces of Uganda

- 5 people: representatives of handicapped people 
- 5 people: representatives of employees

- (18 people: official representatives, ex-officio members. The deputy president or those ministers that were not elected as members of the parliament become exofficio members. They have no right to vote.)

According to the new effective laws governing the elections in 1996, the inhabitants of the constituencies - instead of the electoral colleges - vote directly for the candidates; those are the 290 members mentioned above (Tripp, 2000: 231). The mandate of the unicameral parliament is for 5 years and the elections are carried out by simple majority voting. Officially, they have a multi-party system and hold democratic elections, but in reality, they have a sham democracy. According to paragraph 5 in the Constitution, all at least 18-year-old Ugandan citizens are allowed to vote. In fact, imprisoned and arrested citizens are not allowed to vote, even though the constitution does not restrict or forbid this right of theirs. Due to a modification in 2005, only those who register themselves are allowed to cast their votes (IFES, 2016: 1). Based on the same modification of the law, the president can be re-elected unlimited times.

\section{Gender quota regulations and the status of women in Uganda}

The first significant year concerning female political representation is 1989. During the elections that year, a party called National Resistance Council supported and encouraged women to become representatives in the parliament. As a result, $17 \%$ of their own politicians were women in the end (Kadaga, 2013: 8). This was a major breakthrough for women in Uganda, because, just like other African countries, the society of Uganda has also been strictly patriarchal. Women have had no possibilities to fill in any decision-making positions at both local and national level. 1989 made children-educating and family-feeding Ugandan women visible. The next important step was in 1995, when according to the $1 \mathrm{~b}$ clause of paragraph 78 in the new constitution, every district had to elect at least one female politician. Since the country had 112 districts at this time (the number of districts and constituencies had been growing over the decades), female political representation had to mean minimum 112 representatives in the parliament (The Constitution of the Republic of Uganda, 1995). Female politicians are elected directly but separately from the 290 straight elected politicians. Every district that consists of 3 counties elects a

\section{This was a major breakthrough for women in Uganda, because, just like other African countries, the society of Uganda has also been strictly patriarchal. Women have had no possibilities to fill in any decision-making positions at both local and national level.}


female politician (Kadaga, 2013: 10). In addition to the 112 mandates, minimum 2 positions out of the 5 representatives of the handicapped, employees and youth, respectively, had to be filled with female politicians. In case of the representatives of the defence forces, the number had to be minimum 3 out of 10. Apart from the prescribed number of positions for women, they also have the chance to get into the parliament from the constituencies with the majority of the votes. Unfortunately, there is still a considerable gap between the number of female and male candidates that are directly elected by the residents of the constituencies (WDG, 2016: 16). As it is shown, female representation in this area is only $15 \%$. Based on the data from January 2017, there are 154 female politicians out of the 449 members of the parliament, which means $34 \%$ representation.

Tamale criticizes the quota system of Uganda as follows: The National Resistance Movement (NRM) is simply descriptive; it only provides a descriptive representation for female politicians. The state of Uganda was not developed enough to integrate a politician in the parliament that had real substantive representation and decisionmaking position. The problem of introducing the gender quota was enhanced by the fact that instead of keeping the number of mandates and share it again between men and women, they were simply keeping the original amount of male representatives and added female to it. The gender quota of Uganda was a top-down act, so female politicians had to integrate into a masculine political structure of a strictly patriarchal system. Most female politicians were appointed by the wise man of the districts in 1989. It is then clear that grass-root female movements were missing from the Ugandan society that would have helped women getting mandates through representing their own interests. The attitude of president Museveni is also not supporting the effective work of female politicians; he has several times emphasized that the gender quota in Uganda is not more than a symbolic gesture, just to show kindness to women (Tamale, 2004: 4-5).

\section{The development of female politics of RPF and NRM}

Powley and Longman separately analyze the relation between RPF and the women reacting to the genocide. They both agree that the government of Rwanda (RPF) treated the emancipation and integration of women into politics with high priority in the post-conflict peace-establishing process (Powley, 2005: 159; Longman 2006: 139). Women were not only appointed to high government positions but also to local decision-making ones. RPF opened the gate for female politicians, it has constantly been extending their rights to support the emancipation of Rwandan women. Both researchers draw a parallel between the RPF and the Ugandan National Resistance Movement led by Museveni. A strong aspect of this parallel is that RPF was formed in Uganda. RPF was set up by the Tutsi Rwandan refugees living in Uganda in 1980. In this period (the second legislative period of President Milton Obote), both Rwandan economical immigrants and refugees were continuously harassed. As an example, in 1982, many Rwandan refugees tried to go back to their home country from Uganda, but they were turned back by the soldiers of Habyarimana saying that there was not 
enough land for them (Longman, 2006: 140). The importance of RPF being present in Uganda was that the Ugandan politics had an influence on them that resulted in parallel features in their structures and their gender politics (Powley, 2005: 159). The military branch of RPF, the Rwandan Patriotic Army had similar structures to the National Resistance Army of Museveni. RPA, just like NRA, defined itself as a party after taking the power in July 1994 (in the case of Rwanda). Both NRM and RPF made the extension of the rights of women and their integration into politics a high priority; and both states introduced a gender quota (Uo. 2006: 140). I discuss the comparison of the female political representation in the parliament of Uganda and Rwanda later.

It is sure that women did not only start to be an important part of the politics of RPF when they gained power in 1994, but also when RPF had still been a military organization in Uganda. (Powley, 2005: 159). Rose Kabuye was known as one of the confidants of Colonel Kagame, who served in the RPA. She was the mayor of Kigali in 1994, later she became a member of the parliament, where she was the leader of the Security and Defence Committee. Later on, she allegedly lost her position in Kagame's confidence circle, but she still held an influential position in the Political and Judicial Commission. Paul Kagame's first head advisor was also a woman, Soline Nyirahabimana. Apart from this position, she was also the member of the National Commission for Human Rights, and later on, she became an ambassador in Switzerland (Longman, 2006: 141-142). The strong female presence during the time spent as refugees in Uganda had created such a solid platform for women in Rwanda that made it possible to build on after the return of the RPF in the post-conflict period. As Powley mentions, liberal rhetoric and gender sensitivity were peculiar for the members of RPF, because Rwandan Tutsi refugees in Uganda and Tutsi women experienced constant harassment, so they knew a lot about exclusion and discrimination (Powley, 2005: 159). The liberal constitutional process and gender-sensitive law-making were shadowed by the monocracy of the one-party system of RPF and NRM in Uganda. In this case, we can ask the question: to what extent did RPF and NRM want to legitimize their own authoritarian power by withholding the promotion of gender issues? Next, I discuss the steps taken in reality to extend female rights and female political representation.

\section{Political role-taking of women in Rwanda ${ }^{2}$}

I made field research in Rwanda in 2015 and 2016. I made in-depth interviews with the qualitative method and I chose my interviewees with the snowball method ${ }^{3}$. I made three groups based on a thematic structure. The third group contains interviews with national and international civil organizations, but they are not involved in this paper because of space limitations.

\section{Interviews made with members of the parliament}

I focused on finding out what motivated my interviewees to choose a political career (e.g.: Did the $30 \%$ quota have any influence on it?). Had they ever encountered any 
situations where the fact that they were women was either an advantage or disadvantage? What gender equality programs were they working on and what civil organizations were they cooperating with?

\section{Interviews made with government agencies}

Apart from the questions asked about the activities of the institutions, I focused on the resistance to the gender programs and the effectiveness of the work in the rural, underdeveloped areas. Could each Rwandan citizen equally profit from the programs of the given institutions? It was important that according to my interviewees the main achievements (by the institutions) since the 1994 genocide were the biggest problems to be solved.

In the history of Rwanda and the advocacy of women, it is important to mention that gender equality and female advocacy have been highly emphasized since the genocide in 1994 and by the norms of the new, ratified constitution in 2003. One of the reasons is the demographic disproportion caused by the genocide because $70 \%$ of the society were women and girls (JEEAR4, 1996: 29). There were also several widows or women who lost everything, thus, they had to find a way to provide their remaining healthy or handicapped family members with everything they need. It must also be mentioned that apart from the abovementioned reasons it was very important for Paul Kagame to show the international community that Rwanda stood for democratic values where female political representation and advocacy had been an important element during the restoration period. The government had a lot to do to establish gender equality after the genocide since Rwanda was strictly patriarchal, where women were definitely subordinated to men before new laws and regulations in the 1990s. Women, apart from taking care of their family members, were not allowed to inherit or possess land or take a loan from a bank. A drastic and fast intervention was necessary in order to provide equal rights for Rwandan men and women at least on the legal level. The period between 1994 and 2003 is called the post-conflict or interim period, during which huge steps were made towards establishing the legal and social equality between Rwandan men and women thanks to the active work of the international and local civil organizations and politicians. Rwanda was declared to be a presidential democracy in the new constitution in 2003. They held the first democratic elections. The constitutional quota prescribes a $30 \%$ female representation in the parliament. The Senate consists of 26 members, out of 12 are elected by local councils, 4 are appointed by the Forum of Political Organizations, 8 are

In the history of Rwanda and the advocacy of women, it is important to mention that gender equality and female advocacy have been highly emphasized since the genocide in 1994 and by the norms of the new, ratified constitution in 2003. 
appointed by the president, and 2 are delegated by the universities. Therefore, 53 out of 80 members of the House of Representatives are elected directly. 24 female representatives are elected by local organizations. (This alone ensures the $30 \%$ female representation. In addition to this, parties apply a quota for women on their party list.) Two representatives are appointed by youth organizations and one is delegated by the organizations of the handicapped. The example of Rwanda perfectly demonstrates that the most successful and effective way to increase the ratio of the female representatives is to set up a quota in the constitution (Rwanda's Constitution, 2003: Article 75).

Apart from the positive changes, it must be emphasized that the international community still doubts whether the political system of Rwanda is democratic. According to Human Rights Watch and Amnesty International, the political system of Rwanda is reported to be oppressive and authoritarian, where the opposition has no real influence on the politics of Paul Kagame and his party in power since the genocide. On the other hand, the UN recognizes the achievements of Rwanda, Paul Kagame is a regular lecturer at events and conferences of these organizations about establishing gender equality. We can observe an ambivalent relationship between international organizations and Rwanda. Female politicians and members of civil organizations achieved several modifications in the legal system that supported the emancipation of women. I would like to highlight some of these modified laws (Government of Rwanda, 2016: 11):

1. Law 59/2008 states that violence against women must be punished;

2. Law 43/2013 states that man and women have equal right to use and possess land;

3. Law 27/2001 protects the rights of children and punishes violence against them;

4. Law 10/20/2013 forbids all gender, race or religious discrimination within the parties;

5. Law $13 / 2009$ states that male and female employees have the same right at their working place and must receive the same payment for the same job, and sexual harassment at the working place must be punished;

6. Law 12/2013 states that the budget of Rwanda should be gender-sensitive, which means that the effect of the different resource allocations and program-efficiency must be measurable in the impact on society.

\section{The Rwandan Gender Machinery}

Establishing and sustaining gender equality in Rwanda are achieved by a system of institutions, the Gender Machinery, resting on 4 pillars that are the Ministry of Gender and Family Promotion, the Gender Monitoring Office, the National Women's Council, and the Forum of Rwandan Women Parliamentarians. I will introduce their general activities briefly, then their current activities based on the interviews, and finally, I will summarize their achievements and their current problems to be solved. 1. Ministry of Gender and Family Promotion (MIGEPROF): Gained its name in 2005, but the ministry itself was founded in 1994 after the genocide in order to create a frame of institutions for the organizations establishing gender equality. 
My interviewee, Batete Redempter, Director of Gender Promotion in the ministry, told me that the most important activities in the ministry are the expansion of the capacities within each sector and the further professional education of the employees. According to Redempter, gender sensitivity is not an innate property of the society. The establishment of equality between men and women is a long process, so it is very important that the employees of the ministry are professionally well-educated. She named the involvement and the treatment of Rwandan men as partners as one of the main challenges. According to her, President Kagame is a very good example in this matter since he is one of the determining figures of the UN campaign "He for She", and he is a regular lecturer at international forums. The program was launched in 2015 and it focuses on three major areas: the support of participation of girls in the info-communicational market, their chance to attend vocational and technical schools, and to curb the violence against women. As a critical point, she mentioned the high rate of poverty among women, and illiteracy, especially among middle-aged women. The main problem with illiterate women is that they do not know their rights and they are not able to ask for help in case they experience violence. To my question concerning how the ministry reaches them the answer was the strong cooperation with NWC. As a structured institution, it is present down to the village level. For example, a village of 100 inhabitants has 7 representatives of NWC.

2. National Women's Council (NWC): organizes, mobilizes, and supports the participation of Rwandan women in national development. It has councils at local level.

3. Gender Monitoring Office (GMO): It is not only active in the state sector but also in the private, economic, political, and civil sector. They register and measure the effectiveness of national and international gender strategies and programs; then they write reports based on various indicators. I asked my interviewee, Cyizanye Allen (Director of Violence and Injustice Committed Against Women Monitoring Department) about the currently most important project. She highlighted the province-level monitoring of stopping violence against women. Their aim is to compare the effectiveness of different provinces. They are, of course, in a tight cooperation with the other institutions of the Gender Machinery and they also send data to the ministry to prepare a gender-sensitive budget. Allen also highlighted the organization of gender-sensitive audits in the private and civil sector, during which they control how a company or a hotel keep the laws and regulations concerning male and female equality. To my question concerning the situation of the women living in poverty in rural areas, she mentioned that a high number of these women endure violence, so they still have a lot to do in this area. According to her, the main goal is to make the whole society understand what male and female equality means. She mentioned that apart from the effective work, such stereotypes that women are homemakers are still strong. She said that the society still considers it taboo or even men express their displeasure if a woman, previously working in the household, starts a political career. The third 
challenge next to poverty and cultural stereotypes is to integrate men in gender programs. Men still have the misunderstanding that gender questions are only the problem of women.

4. Forum for Women Parliamentarians in Rwanda (FFRP): It was founded in 1996. Its goal is to fight for women's rights, to support female role-taking in politics and in the society, and to take measures against the violence against women. This forum discusses only questions concerning women, and the male and female representatives are without political affiliation. FFRP has currently 91 members, out of these 29 are men. The 24 elected women to the parliament are automatically members of the FFRP. These female politicians are independent representatives as prescribed in the constitution, but during the interviews, I had the feeling that they were RPF sympathizers. Most of my interviewees felt the need to help their fellow citizens and local communities after the genocide. We can talk about the appearance of a sense of mission. Most women completed their university studies abroad (e.g. in Uganda or Senegal), but this sense of mission motivated them to return to Rwanda. Their Tutsi played a major role in staying and completing their studies abroad. The compulsory $30 \%$ quota was an additional motivation for them to choose a political career. They all had to face the problems deriving from the stereotypes of traditional female roles. One of my interviewees told me that she had to fight for a long time not to have stage fright when she had to talk in front of a crowd. Another representative's marriage ended in divorce, because instead of doing the household chores, she chose to be a politician. My third interviewee had to learn to drive the motorbike to be able to go to the neighboring village to campaign. They all said that there was no resistance against gender strategies in the rural areas. As the interviewees at other institutions, they also named the mindset as a need; the society must understand that the gender issue is not only the problem of women, but it is the interest of the whole society. They named Agathe Uwilingiyimana and Aloise Inyumba as female role models.

It is visible that these four organizations do an outstanding job in establishing equality between men and women. I highlighted only the critical points of the answers of my interviewees because of space limitations and because their strategies are available on the internet or in other publications. In the end, I would like to highlight that the laws

I would like to highlight that the laws and regulations of the past 20 years have redefined the role of Rwandan women in the society. The reason why the work to establish equality between men and women is so effective is that the all-powerful state considers it as one of its main tasks and stands fully behind it. 
and regulations of the past 20 years have redefined the role of Rwandan women in the society. The reason why the work to establish equality between men and women is so effective is that the all-powerful state considers it as one of its main tasks and stands fully behind it. The emancipation of women is some kind of national image. The representatives of GMO, MIGERPRO, and FFRP were eager to talk about their achievements. My experience during the interviews was that my interviewees liked putting Rwanda in a position as if it would have managed all gender-related activities on its own, but in reality, the international community takes a big (financial) role also. The citizens of the country have not yet been able to adjust to this extremely fast progress. The institutions are conscious about this; that is the reason why all representatives of GMO, MIGERPROF, and FFRP said that "it is a procedure that has not yet come to an end".

As a conclusion, we can point out that Rwanda can be an example for other African countries in the sense of gender-sensitive policy-making. It is a fact that the Rwandan society still has to overcome traditional patriarchal beliefs. The shift from a strictly patriarchal society cannot happen in such a short time. It is also important to emphasize that there is still much work to do on the practical level to achieve gender equality. On the other hand, we can state that Rwanda has produced the best result not only among EAC countries but in the Sub-Saharan African context as well.

\section{Notes}

1 Emera ERoronsisok Supported by the ÚNKP-17-3 -IV.-PTE-277 New National Excellence Program of the Ministry of Human Capacities.

2 This part of the article is up to be released in Hungarian language in 'Afrikai nök politikai és társadalmi helyzete’ In Afrika a globalizált világban - lehetőségek és kihívások, Dialóg Campus Kiadó.

3 According to Earl Babbie, the snowball method is when the researcher collects data from a given group of the population and then asks them to provide them with the contact data of other known members of the same population. Babbie recommends to apply this method to examine political groups (Babbie, 2008: 206-207), which is relevant in our case.

\section{Bibliography}

- Africa Election Guide. (2016). http://www.electionguide.org/elections/id/2754/ [05.02.2018]

- Amnesty International (2017). International Annual Report on Rwanda (2016/2017). https:// www.amnesty.org/en/countries/africa/rwanda/report-rwanda/ [05.05.2018]

- Babbie, E. (2008). A társadalomtudományi kutatás gyakorlata. [The Practice of Social Science Research] Balassi Kiadó, Budapest.

- East African Community. (2011). EAC Strategic Plan for Gender, Youth, Children, Persons with Disability, Social Protection and Community Development (2012-2016). https://www.ilo. org/dyn/natlex/docs/MONOGRAPH/94021/110206/F705470476/INT-94021.pdf [03.25.2018]

- Electoral Commission Uganda. (2016). http://www.ec.or.ug/?q=content/2016-general-elections-statistics [28.04.2018]

- Inter-Parliamentary Union. (2016). Uganda Parliament. Last elections. http://archive.ipu.org/ Parline/reports/2329_E.htm [04.25.2018] 
- Inter-Parliamentary Union World Classification. (2018). http://archive.ipu.org/wmn-e/classif. htm [03.25.2018]

- Kadaga, R. (2013). Women's political leadership in East Africa with specific reference to Uganda. In: Robertson and Jones-Parry, R. (Eds.). Commonwealth Governance Handbook 2013/14: Democracy, development and public administration 2013-2014, 32-36. http://www. commonwealthgovernance.org/assets/uploads/2013/11/6-Womens-political-leadership-eastafrica.pdf [02.03.2018]

- National Elections Act of South Sudan. (2012). Act. No. 39. Juba, April, 2012. http://aceproject. org/ero-en/regions/africa/SS/south-sudan-the-national-elections-act-no.-39-of/at_download/ file [02.15.2018]

- Parliament of the Republic of Uganda. (n.d.). http://www.parliament.go.ug/new/index.php/ about-parliament/composition-of-parliament [02.15.2018]

- Republic of Uganda Electoral Commission. (2016). http://www.ec.or.ug/docs/Report\%20 on\%20the \%202015-2016\%20General\%20Elections.pdf [04.20.2018]

- Steering Committee of Joint Evaluation of Emergency Assistance to Rwanda (JEEAR4). (1996). The International Response to Conflict and Genocide: Lessons from the Rwanda Experience: Rebuilding Post-War Rwanda. Study 4, Copenhagen.

- Tamale, S. (2004). Introducing Quotas in Africa: Discourse and Legal Reform in Uganda. http://www.quotaproject.org/CS/CS_Uganda_Tamale-6-6-2004.pdf [04.20.2018]

- Tarrósy, I. (2011). Kelet-Afrika a fejlödés útján. [East Africa on the Road to Development] Publikon Kiadó, Pécs.

- The Commonwealth. (2018). Uganda. Constitution and politics. http://thecommonwealth.org/ our-member-countries/uganda/constitution-politics [22.04.2018]

- The Constitution of Burundi. (2005). https://www.constituteproject.org/constitution/ Burundi_2005.pdf [03.25.2018]

- The Constitution of Kenya. (2008). http://www.kttc.ac.ke/images/Constitution_of_Kenya.pdf [03.25.2018]

- The Constitution of South Sudan. (2011). https://www.constituteproject.org/constitution/ South_Sudan_2011.pdf [03.25.2018]

- The Constitution of Tanzania. (2005). http://www.wipo.int/edocs/lexdocs/laws/en/tz/tz008en. pdf [03.25.2018]

- The Electoral Commission. General Parliamentary Elections 2016. http://www.ec.or.ug/sites/ default/files/docs/Gazette\%20List\%20Elected\%20MPs\%202016.pdf [03.20.2018]

- Tripp, A. M. (2000). Women \& Politics in Uganda. The University of Wisconsin Press, USA.

- Women's Democracy Group. (2016). Report on Gender and Women's Participation in the 2016 Elections in Uganda (2016). http://www.cewigo.org/sites/default/files/reports/second report_on_gender_and_womens_participation_in_2016_elections-nov_2015-jan_2016.pdf [03.19.2018] 